\title{
Cloning, expression, purification and characterization of chitin deacetylase extremozyme from halophilic Bacillus aryabhattai B8W22
}

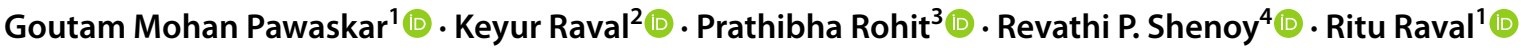

Received: 11 October 2021 / Accepted: 22 November 2021 / Published online: 1 December 2021

(c) The Author(s) 2021

\begin{abstract}
Chitin deacetylase (CDA) (EC 3.5.1.41) is a hydrolytic enzyme that belongs to carbohydrate esterase family 4 as per the CAZY database. The CDA enzyme deacetylates chitin into chitosan. As the marine ecosystem is a rich source of chitin, it would also hold the unexplored extremophiles. In this study, an organism was isolated from $40 \mathrm{~m}$ sea sediment under halophilic condition and identified as Bacillus aryabhattai B8W22 by 16S rRNA sequencing. The CDA gene from the isolate was cloned and overexpressed in $E$. coli Rosetta pLysS and purified using a Ni-NTA affinity chromatography. The enzyme was found active on both ethylene glycol chitin (EGC) and chitooligosaccharides (COS). The enzyme characterization study revealed, maximum enzyme velocity at one hour, optimum $\mathrm{pH}$ at 7 with $50 \mathrm{mM}$ Tris- $\mathrm{HCl}$ buffer, optimum reaction temperature of $30^{\circ} \mathrm{C}$ in standard assay conditions. The co-factor screening affirmed enhancement in the enzyme activity by $142.43 \pm 7.13 \%$ and $146.88 \pm 4.09 \%$ with substrate EGC and COS, respectively, in the presence of $2 \mathrm{mM} \mathrm{Mg}^{2+}$. This activity was decreased with the inclusion of EDTA and acetate in the assay solutions. The enzyme was found to be halotolerant; the relative activity increased to $116.98 \pm 3.87 \%$ and $118.70 \pm 0.98 \%$ with EGC and COS as substrates in the presence of $1 \mathrm{M} \mathrm{NaCl}$. The enzyme also demonstrated thermo-stability, retaining $87.27 \pm 2.85 \%$ and $94.08 \pm 0.92 \%$ activity with substrate EGC and COS, respectively, upon treatment at $50^{\circ} \mathrm{C}$ for $24 \mathrm{~h}$. The kinetic parameters $K_{\mathrm{m}}, V_{\max }$, and $K_{\text {cat }}$ were $3.06 \mathrm{E}-05 \mu \mathrm{g} \mathrm{mL}^{-1}, 3.06 \mathrm{E}+01 \mu \mathrm{M} \mathrm{mg}^{-1} \mathrm{~min}^{-1}$ and $3.27 \mathrm{E}+04 \mathrm{~s}^{-1}$, respectively, with EGC as the substrate and 7.14E-07 $\mu \mathrm{g} \mathrm{mL}-1,7.14 \mathrm{E}+01 \mu \mathrm{M} \mathrm{mg}^{-1} \mathrm{~min}^{-1}$ and $1.40 \mathrm{E}+06 \mathrm{~s}^{-1}$, respectively, with COS as the substrate. The enzyme was found to be following Michaelis-Menten kinetics with both the polymeric and oligomeric substrates. In recent years, enzymatic conversion of chitosan is gaining importance due to its known pattern of deacetylation and reproducibility. Thus, this $B a C D A$ extremozyme could be used for industrial production of chitosan polymer as well as chitosan oligosaccharides for biomedical application.
\end{abstract}

Keywords Receptor plate assay - Bacillus aryabhattai B8W22 - Chitin deacetylase extremozyme $\cdot$ Lactose induction . Halotolerant · Thermostable

\section{Introduction}

Chitin is the second-most abundant biopolymer followed by cellulose. The application of chitin is limited due to its crystalline structure and insoluble property. Chitosan is the deacetylated form of chitin, soluble in slightly acidic conditions. The cost-effective commercial synthesis of chitosan is done by chemical deacetylation (Mathew et al. 2021). The chemical conversion compromises the quality of chitosan concerning reproducibility in physiochemical properties

Ritu Raval

ritu.raval@manipal.edu

Extended author information available on the last page of the article like degree of polymerization (DP), degree of acetylation (DA) and the pattern of acetylation (PA) (Cord-Landwehr et al. 2020; Wattjes et al. 2020). The volumes of effluents generated in the chemical process also add to an environmental load of pollutants. Over the years, several studies have shown the medical application of chitosan, but the use of chemically converted chitosan is limited due to its physicochemical properties. Therefore, enzymatic deacetylation of chitin is gaining attention for medical applications $(\mathrm{Hu}$ et al. 2021).

Chitin deacetylase (CDA) (EC 3.5.1.41) is a hydrolytic enzyme that belongs to carbohydrate esterase family 4 (CE-4 s) as per the CAZY database (Carbohydrate Active Enzymes database), URL (http://www.cazy.org) (Lombard 
et al. 2014; Andreou et al. 2018). CDA hydrolyses the acetamido group in chitin to form chitosan, releasing acetic acid as a by-product (Pawaskar et al. 2019). Structurally, the CE-4 family enzymes share the NodB homology domain or polysaccharide deacetylase catalytic domain as a conserved region. In some studies, the chitin-binding domain is also reported (Grifoll-Romero et al. 2018). The first CDA discovered from Mucor rouxii fungus and Colletotrichum lindemuthianum is the most-studied organism for its CDA activity (Ghormade et al. 2010). Other fungi like Aspergillus flavus, Mortierella sp., Absidia coerulea, Rhizopus circinans, Penicillium oxilium, and bacteria like Vibrio alginolyticus, Bacillus sp., Alphaproteobacteria have been recently reported for their CDA activity (Kaczmarek et al. 2019).

As the commercial source of chitin is marine waste, the interest in isolating CDA-producing micro-organisms from aquatic sources has increased (Mathivanan et al. 2021). In the previous study, we reported a rapid and sensitive agarbased CDA screening method (Pawaskar et al. 2019). In the present finding, we report the isolation of halophilic bacteria from sea sediment at a depth of $40 \mathrm{~m}$ for CDA activity using this novel receptor-based screening method (Pawaskar et al. 2019). The bacteria having maximum CDA activity was later identified as Bacillus aryabhattai B8W22. The CDA gene from B. aryabhattai B8W22 (BaCDA) was cloned and heterologously expressed in $E$. coli Rosetta pLysS cells. The $\mathrm{BaCDA}$ was purified using Ni-NTA affinity chromatography and characterized with ethylene glycol chitin (EGC) and chitin oligosaccharide (COS) as substrates. Enzyme kinetic parameters were also determined.

\section{Materials and methods}

\section{Chemicals and reagents}

Ethylene glycol chitosan (EGCS), Chitin oligosaccharide (COS), Empty polypropylene SPE Tube with PE frits, and Primers were purchased from Sigma Aldrich, India. Q5 Hifidelity Taq DNA polymerase, restriction enzymes, DNA ligase, and Monarch ${ }^{\circledR}$ Plasmid Miniprep Kit were purchased from New England Biolabs (NEB) India. PCR product/gel extraction kit was purchased from Promega India. A glucose assay kit was purchased from Agappe diagnosis Pvt. Ltd., India. Ni-NTA agarose beads were purchased from QIAGEN India Pvt. Ltd., India. Dialysis membrane was purchased from Thermo-fisher scientific India, Amicon ${ }^{\circledR}$ Ultra15 Centrifugal Filter Unit was purchased from Merck-Millipore, India. Acetate calorimetric assay kit was purchased from Megazyme (Ireland). All other chemicals and reagents were of analytical grade.

\section{Plasmid, bacterial strains, and culture media}

pET22b (+) DNA-Novagen was purchased from MerckMillipore, India, and stored at $-20^{\circ} \mathrm{C}$. E. coli DH5 $\alpha$ and E. coli Rosetta pLysS-Novagen cells were purchased from Merck-Millipore, India, and maintained in Luria-Bertani (LB) broth containing $25 \%$ glycerol at $-80{ }^{\circ} \mathrm{C}$. Bacillus aryabhattai $\mathrm{B} 8 \mathrm{~W} 22$ was isolated in our lab and maintained in Nutrient Broth (NB) containing $25 \%$ glycerol at $-80^{\circ} \mathrm{C}$.

\section{Sample collection, isolation, and screening of CDA-producing bacteria}

An Arabian Sea sediment sample was collected from a depth of $40 \mathrm{~m}$ using Ekman dredge with the coordinates as $12^{\circ} 48^{\prime} \mathrm{N}$ and $74^{\circ} 40^{\prime} \mathrm{E}$. The sample was transported in a sterile container to the laboratory immediately and stored in a cold room till further use (Anas et al. 2016). A 100 $\mu \mathrm{L}$ of serially diluted sample solutions was inoculated by spread plate method on the colloidal chitin plate containing $\mathrm{NaNO}_{3}-2 \mathrm{~g} \mathrm{~L}^{-1}, \mathrm{~K}_{2} \mathrm{HPO}_{4}-1 \mathrm{~g} \mathrm{~L}^{-1}, \mathrm{KH}_{2} \mathrm{PO}_{4}-1 \mathrm{~g} \mathrm{~L}^{-1}$, $\mathrm{MgSO}_{4}-0.5 \mathrm{~g} \mathrm{~L}^{-1}$, colloidal chitin-1\% (w/v) and agar$2.5 \%(\mathrm{w} / \mathrm{v})$ at final concentration, dissolved in synthetic seawater (Anas et al. 2016; Pawaskar et al. 2019). The plate was cultured for 7 days at $37^{\circ} \mathrm{C}$. The isolated bacteria were sub-cultured multiple times on a fresh colloidal chitin plate to get a purified single colony. The purified single colony was spot inoculated on a receptor-based screening plate for CDA activity.

\section{Crude enzyme activity of the isolates}

The positive isolates from the receptor plates were inoculated in liquid broth containing $\mathrm{NaNO}_{3}-2 \mathrm{~g} \mathrm{~L}^{-1}$, $\mathrm{K}_{2} \mathrm{HPO}_{4}-1 \mathrm{~g} \mathrm{~L}^{-1}, \mathrm{KH}_{2} \mathrm{PO}_{4}-1 \mathrm{~g} \mathrm{~L}^{-1}, \mathrm{MgSO}_{4}-0.5 \mathrm{~g} \mathrm{~L}^{-1}$, colloidal chitin-1\% (w/v) at final concentration, dissolved in synthetic seawater. After culturing the isolate for $48 \mathrm{~h}$ at $37^{\circ} \mathrm{C}$ with $180 \mathrm{rpm}$ agitation, the supernatant was collected as crude extract followed by centrifugation at $5405 \mathrm{~g}$ for $10 \mathrm{~min}$ at $4{ }^{\circ} \mathrm{C}$. The extracellular CDA activity of the crude extract was determined by acetate assay kit as per the manufacturer's instructions. Ethylene glycol chitin (EGC) was used as a substrate for the reaction (Araki and Ito 1988). One unit of the enzyme is defined as the activity which released $1 \mu \mathrm{mol}$ of acetate from the substrate per microgram of enzyme per minute. All the enzyme assays were carried out in triplicates and corrected for background from control reactions, one without enzyme and another without substrate (Raval et al. 2013, 2017). 


\section{Identification of bacteria having maximum CDA activity}

The isolate yielding maximum CDA activity was identified by $16 \mathrm{~S}$ rRNA gene analysis. $16 \mathrm{~S}$ rRNA gene was amplified using 27F: AGA GTT TGA TCM TGG CTC AG and 1492R: CGG TTA CCT TGT TAC GAC TT as forward and reverse primer, respectively. By Sanger sequencing, the 16S rRNA gene was analysed and compared with the gene database using the BlastN algorithm to determine the relative position of strain in phylogeny. Multiple sequence alignment of the top 10 blast hit was done using the MUSCLE algorithm and a phylogenetic tree was constructed using MegaX software. The isolate was identified by the closest neighbouring strain in the phylogenetic tree (Kim and Chun 2014; Kumar et al. 2018).

\section{Gene identification, annotation, and cloning}

The homology-based comparative approach was used to predict the CDA gene sequence. In brief, an already reported putative CDA gene sequence from highly related species was retrieved from the NCBI gene database. These sequences were used to search the whole genome sequence of the isolate by the BLAST server. The homologous region was annotated as the CDA gene in the NCBI gene data bank.

A set of primers (forward primer: 5'-GCCGCCGCAT ATGATGAATATGTTTTATAC-3' and reverse primer: 5'-GTATCTCGAGGCGGATATCTTTTACTTG-3') was designed using Benchling web tool (https://benchling.com). The primer was designed to include NdeI and XhoI restriction sites in the sequence. A virtual clone was constructed using SnapGene software (https://www.snapgene.com). The designed primer was synthesized and purchased by Sigma Aldrich, India.

The Bacillus aryabhattai B8W22 gDNA was isolated using the phenol/chloroform extraction method for the amplification of the CDA gene (Andreou 2013). The optimized PCR condition included 30 cycles comprising denaturation at $94{ }^{\circ} \mathrm{C}$ for $10 \mathrm{~s}$, annealing at $58^{\circ} \mathrm{C}$ for $30 \mathrm{~s}$, extension at $72{ }^{\circ} \mathrm{C}$ for $60 \mathrm{~s}$. The amplified gene product was purified as per the user's manual. The amplified $B a C D A$ gene and pET22b (+) vector were digested with $N d e I$ and $X h o I$ restriction enzymes and purified as per the user's manual. The digested vector and insert were ligated in the ratio $3: 1$ using a T4 DNA ligase at $16{ }^{\circ} \mathrm{C}$ for $16 \mathrm{~h}$. The ligated product was transformed into E. coli $\mathrm{DH} 5-\alpha$ competent cells and plated on LB agar plate containing ampicillin antibiotic $(100 \mu \mathrm{g} \mathrm{mL})$. The successful cloning in the transformed cells was verified by colony PCR and restriction digestion of the isolated plasmid. The final confirmation of the insert was achieved by PCR using universal $\mathrm{T} 7$ promoter and T7 terminator primers. Homology modelling with PDB ID $1 \mathrm{~W} 17,2 \mathrm{C} 1 \mathrm{G}, 2 \mathrm{CC} 0,2 \mathrm{IW} 0$, and $2 \mathrm{Y} 8 \mathrm{U}$ was undertaken for the translated cloned sequence. The conserved region in $\mathrm{BaCDA}$ was determined by ESPript 3.0 (http://espript.ibcp.fr) online tool (Robert and Gouet 2014).

\section{Expression and purification of $\mathrm{BaCDA}$}

The cloned plasmid was transformed into E. coli Rosetta pLysS competent cells and plated on LB chloramphenicol (35 $\left.\mu \mathrm{g} \mathrm{mL}^{-1}\right)$, ampicillin $\left(100 \mu \mathrm{g} \mathrm{mL}^{-1}\right)$ agar plate. The overexpression of recombinant $\mathrm{BaCDA}$ was optimized by one variable at a time method. The variables considered were temperature, induction $\mathrm{OD}_{600}$, IPTG concentration, induction time and induction media.

The overexpressed cells were centrifuged at $5405 \mathrm{~g}$ for $10 \mathrm{~min}$ at $4{ }^{\circ} \mathrm{C}$ for harvesting. The lysate was prepared by adding $5 \mathrm{~mL}$ of lysis buffer $(50 \mathrm{mM}$ Tris- $\mathrm{HCl}$ buffer $\mathrm{pH} 8$, $300 \mathrm{mM} \mathrm{NaCl}, 5 \mathrm{mM}$ imidazole) to each gram of pellet. The lysis included 20 cycles of sonication with $5 \mathrm{~s}$ on and $10 \mathrm{~s}$ off phase. The amplitude maintained for lysis was $60 \%$. All the experiments were performed on ice. The lysate was collected after centrifugation at $5405 \mathrm{~g}$ for $10 \mathrm{~min}$ at $4{ }^{\circ} \mathrm{C}$. The lysate was then subjected to purification by the Ni-NTA affinity chromatography. Briefly, the column was washed with Milli$\mathrm{Q}$ water and equilibrated with lysis buffer. The $\mathrm{BaCDA}$ in the lysate was allowed to bind to the Ni-NTA column by passing through gravity flow. The column was washed with wash buffer (50 mM Tris- $\mathrm{HCl}$ buffer $\mathrm{pH} 8,300 \mathrm{mM} \mathrm{NaCl}$, $50 \mathrm{mM}$ imidazole, $10 \%$ glycerol) and the bound enzyme was eluted with elution buffer $(50 \mathrm{mM}$ Tris- $\mathrm{HCl}$ buffer $\mathrm{pH}$ $8,300 \mathrm{mM} \mathrm{NaCl}$, X imidazole) with an imidazole concentration of $250 \mathrm{mM}$ and $500 \mathrm{mM}$. The purified elution was pooled and dialyzed at $4{ }^{\circ} \mathrm{C}$ against $50 \mathrm{mM}$ Tris- $\mathrm{HCl}$ buffer pH 8 using a $10 \mathrm{kDa}$ cut-off dialysis membrane. BaCDA was later concentrated using a $10 \mathrm{kDa}$ Amicon ${ }^{\circledR}$ Ultra-15 Centrifugal Filter Unit by centrifuging at $2111 \mathrm{~g}$ for $30 \mathrm{~min}$ at $4{ }^{\circ} \mathrm{C}$. The final yield and purification fold were calculated for the purified $B a C D A$.

\section{Expression scale-up and investigation of lactose induction point}

The expression was scaled up to $1 \mathrm{~L}$ in a shake flask under optimized conditions. The yield was found by measuring the biomass (wet pellet weight). To understand the role of lactose in induction and repression by glucose, sampling at every four hours of the interval was done and the assay parameters were analysed.

\section{Enzyme characterization}

The enzyme was characterized by determining the enzyme activity using EGC and COS as substrates. The initial enzyme activity experiments were carried out in $50 \mathrm{mM}$

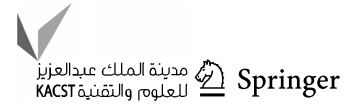


Tris- $\mathrm{HCl}(\mathrm{pH} 7)$ buffer at $37^{\circ} \mathrm{C}$. The enzyme velocity was determined at 30-360 min time intervals. The suitable $\mathrm{pH}$ and buffer conditions were studied by testing enzyme activity in different $\mathrm{pH}$ and buffer conditions. A pH range was of 4-10 using the following buffers: $50 \mathrm{mM}$ citrate buffer (4-6), $50 \mathrm{mM}$ bis-tris buffer (6-7), $50 \mathrm{mM}$ phosphate buffer (6-8), $50 \mathrm{mM}$ Tris-HCl buffer (7-8), $50 \mathrm{mM}$ boric acid buffer (8-9) and $50 \mathrm{mM}$ carbonate-bicarbonate buffer (9-10). The optimum reaction temperature was determined by assaying the $\mathrm{BaCDA}$ activity at various temperatures $\left(20-60{ }^{\circ} \mathrm{C}\right)$.

The effects of monovalent metal ions $\left(\mathrm{K}^{+}, \mathrm{Na}^{+}\right)$, divalent metal ions $\left(\mathrm{Ca}^{2+}, \mathrm{Co}^{2+}, \mathrm{Zn}^{2+}, \mathrm{Mn}^{2+}, \mathrm{Mg}^{2+}, \mathrm{Fe}^{2+}, \mathrm{Ni}^{2+}\right.$, ) and EDTA on the $B a C D A$ activity were estimated by pre-incubating the BaCDA in the $50 \mathrm{mM}$ Tris- $\mathrm{HCl}$ buffer $(\mathrm{pH} 7)$ with a metal ion at a concentration of $1 \mathrm{mM}$. After one hour of reaction, residual activity was measured under standard assay conditions. The activity determined in the absence of metal ions was recorded as $100 \%$. The acetate inhibition on $\mathrm{BaCDA}$ activity was also determined by assaying the enzyme activity in presence of acetate with concentrations ranging from 0.1 to $10 \mathrm{mM}$ under standard assay conditions.

The salt tolerance and thermal stability of $B a C D A$ were determined. The enzyme activity using acetate assay kit at standard assay condition was carried out in presence of $0 \mathrm{mM}$ to $2 \mathrm{M} \mathrm{NaCl}$. The enzyme was incubated for $24 \mathrm{~h}$ at $4{ }^{\circ} \mathrm{C}, 20^{\circ} \mathrm{C}, 30^{\circ} \mathrm{C}, 40{ }^{\circ} \mathrm{C}, 50{ }^{\circ} \mathrm{C}, 60{ }^{\circ} \mathrm{C}, 70{ }^{\circ} \mathrm{C}$, and $80{ }^{\circ} \mathrm{C}$ in optimum buffer, metal ion, and salt condition. After the incubation time, the enzyme activity was assayed to know the thermal stability of the $B a C D A$.

\section{Enzyme kinetics}

The kinetic parameters of purified $B a C D A$ were determined by enzyme activity under optimized conditions using an acetate assay kit. The Michaelis-Menten kinetic constants $\left(K_{\mathrm{m}}\right.$ and $V_{\max }$ ) were calculated by plotting the Lineweaver-Burk graph (Lineweaver and Burk 1934). The substrate EGC at concentrations ranging from 1.00 to $5.00 \mathrm{E}-7 \mu \mathrm{g} \mathrm{mL}{ }^{-1}$ and $\mathrm{COS}$ at a concentration ranging from 1.00 to $1.00 \mathrm{E}-8 \mu \mathrm{g} \mathrm{mL}^{-1}$ were used. The enzyme specificity towards the substrate chain length was determined using two types of substrates.

\section{Results}

\section{Isolation, screening, and identification}

Fifteen morphologically different colonies were observed on the colloidal chitin agar plate after 7 days of incubation. Out of fifteen, four isolates were tested positive for CDA activity, showing fluorescence around the colony on receptor-based screening plate on the fourth day of incubation (Fig. S1). The crude CDA activity of the four isolates was further quantified using acetate assay. The maximum CDA activity of $2.39 \pm 0.16 \mathrm{U} \mathrm{mg}^{-1}$ was observed with the isolate MS7 (Fig. S2). Hence, the molecular identification of MS7 was undertaken. Homology-based analysis of $16 \mathrm{~S}$ rRNA has been a gold standard for bacterial identification. The $16 \mathrm{~S}$ rRNA GenBank BLAST results of the isolate MS7 showed a $99.84 \%$ match with $B$. aryabhattai B8W22 (NCBI Reference Sequence: NR_115953.1). The phylogenetic tree was constructed by selecting homologous sequences with Bacillus niacin strain as the outgroup (Fig. 1). The isolate MS7 has been submitted for general deposition to National Culture for Microbial Resource (NCMR), India with the accession ID: MCC 3987.

\section{Gene identification, annotation, and cloning}

Neighbourhood-based homology search with $B$. megaterium putative polysaccharide deacetylase (Gene ID: NZ_CP009920.1) gene helped to decode the chitin deacetylase gene from $B$. aryabhattai whole genome (Genome ID: NZ_JYOO01000001.1). The B. aryabhattai CDA gene had a $100 \%$ query cover with a $97 \%$ identity with $B$. megaterium putative polysaccharide deacetylase gene. The identified $B$. aryabhattai chitin deacetylase ( $B a C D A$ ) gene was annotated in the NCBI gene databank, and the nucleotide sequence data are available in the third-party section of the DDBJ/ENA/GenBank databases with TPA: BK010747 as the accession number.

The virtual clone plasmid was constructed using SnapGene software (Fig. S3). The BaCDA gene ( $765 \mathrm{bp}$ ) from the genomic DNA of $B$. aryabhattai was amplified with NdeI and XhoI restriction sites incorporated via the primers (Fig. S4). The double restricted (NdeI and XhoI) amplicon was ligated into the NdeI and XhoI digested pET-22b (+) vector. The recombinant vector of size $\sim 6132$ bp was later confirmed by agarose gel electrophoresis. Secondary confirmation was done by amplification with gene-specific primers and double digestion with $\mathrm{NdeI}$ and XhoI restriction enzymes.

$B a \mathrm{CDA}(\mathrm{pET} 22 \mathrm{~b}+)$ was amplified with the $\mathrm{T} 7$ promoter and T7 terminator primer for confirmation of cloning. The nucleotide sequence was translated using BioEdit software (Hall et al. 2011). The structure-based sequence alignment showed that the $\mathrm{BaCDA}$ had a high sequence similarity in the conserved motifs to the existing CDA of other microorganisms. The protein structure has the $(\beta / \alpha)_{8}$ barrel topology that is the characteristic of $\mathrm{CE}-4$ category enzyme (Fig. S5). The sequence consists of a catalytic domain (NodB) at C-terminal with a signal peptide of a 23-amino 


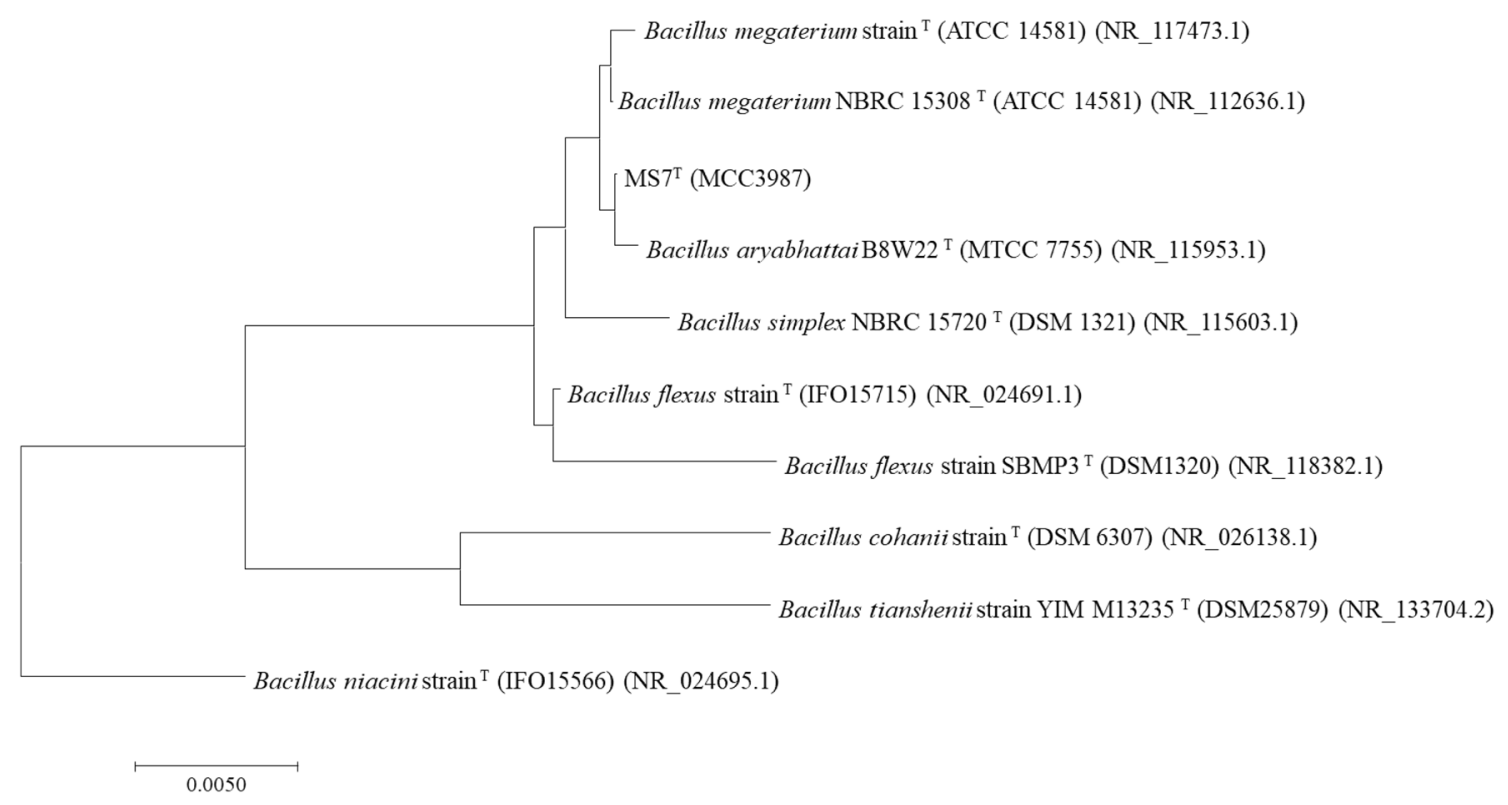

Fig. 1 The Phylogenetic analysis. The phylogenetic tree showing the isolate MS7 was highly homologous with $B$. aryabhattai B8W22 with a $99 \%$ match. The Bacillus niacini was taken as an out-group. The phylogenetic tree was constructed by a maximum parsimony algorithm. The names of the culture collection centres of the type iso-

acid length, with Leucine at $\mathrm{N}$-terminus and valine at the C-terminus (data not shown).

\section{Expression optimization and purification}

The cloned vector was transformed into E. coli Rosetta pLysS cells. The initial expression experiments were performed in Luria-Bertani (LB) medium with $1 \mathrm{mM}$ Isopropyl $\beta$-D-1-thiogalactopyranoside (IPTG) as the inducer. The induced cells at temperatures $37{ }^{\circ} \mathrm{C}$ and $16{ }^{\circ} \mathrm{C}$ were evaluated for soluble expression. The cells induced at $16{ }^{\circ} \mathrm{C}$ showed expression as a soluble intracellular fraction. Other parameters optimized to maximize the expression were, the optical density of the cells at the time of induction, the concentration of IPTG, and the post-induction culture time. Based on these preliminary optimization experiments, the induction $\mathrm{OD}_{600}$ was 0.6 . The optimum concentration of IPTG was $0.1 \mathrm{mM}$ and the $16 \mathrm{~h}$ culture time post induction (Data have not shown). Further expression studies involving IPTG induction were conducted with these optimized conditions.

In addition to the IPTG induction, lactose induction (as auto-inducer) was also tested for the $B a C D A$ expression. Induction conditions with IPTG and lactose were compared in three reported media viz. Luria Bertani (LB), Yeast extract-tryptone broth (2YT), and Terrific Broth (TB). The expression and the growth of the culture were determined lates compared for the phylogenetic tree are American Type Culture Collection (ATCC), Leibniz-Institut DSMZ-Deutsche Sammlung von Mikroorganismen und Zellkulturen GmbH (DSM), Institute for Fermentation, Osaka (IFO), Microbial Type Culture Collection (MTCC)

at an interval of $24 \mathrm{~h}$ and $48 \mathrm{~h}$. After incubation of $24 \mathrm{~h}$, the $B a C D A$ expression (protein corresponding to $29 \mathrm{kDa}$ ) was observed in all the above three media with IPTG as the inducer. In the lactose auto-induction media, no expression was observed at the 24th h (Fig. S6A). The maximum expression at the 24th $\mathrm{h}$ time point was observed in the LB media. Upon extending the culture duration to $48 \mathrm{~h}$, maximum expression was observed in TB lactose auto-induction media (Fig. S6B). Therefore, TB lactose auto-induction medium was used for further experiments.

Using $5 \mathrm{~g}$ of induced cell pellet, $25 \mathrm{~mL}$ of cell lysate was prepared and diluted in $25 \mathrm{~mL}$ of lysis buffer to give a total protein of $275 \mathrm{mg}$ and specific activity of $14.57 \mathrm{U} \mathrm{mg}^{-1}$ (Table 1). The recombinant $B a C D A$ was purified to homogeneity and the apparent molecular weight of the purified $B a C D A$ was $29 \mathrm{kDa}$ (Fig. S6C). The purified $B a C D A$ elutions were pooled, dialyzed, and concentrated. After concentrating, the total recovered protein was $23.10 \mathrm{mg}$ and the specific activity of purified $B a C D A$ was $38.89 \mathrm{U} \mathrm{mg}^{-1}$. The activity yield was $22.42 \%$ and the purification fold was 2.67 (Table 1).

\section{Expression scale-up and investigation of lactose induction}

Based on expression studies, the expression was scaled up to $1 \mathrm{~L}$ in a shake flask under optimized conditions. Meanwhile, 
Table 1 The specific activity and yield of $B a C D A$

\begin{tabular}{lccllr}
\hline Sample & Total protein $(\mathrm{mg})$ & Total activity $(\mathrm{U})$ & $\begin{array}{l}\text { Specific activity (U } \\
\left.\mathrm{mg}^{-1}\right)\end{array}$ & Purification fold & Activity yield (\%) \\
\hline Culture lysate & 275.00 & 4006.75 & 14.57 & 1.00 & 100.00 \\
Purified $\mathrm{BaCDA}$ & 23.10 & 898.36 & 38.89 & 2.67 & 22.42 \\
\hline
\end{tabular}

The enzyme activity and concentration were determined by acetate assay and Bradford's assay, respectively. One unit of the enzyme is defined as the activity which released $1 \mu \mathrm{mol}$ of acetate from the substrate per mg of enzyme per minute. The values correspond to the average and standard deviation of experiments done in triplicates

to demonstrate the lactose induction, the biomass of the culture, glucose concentration, and enzyme activity were estimated. The culture had an initial lag phase of $16 \mathrm{~h}$ followed by the first exponential phase lasting for the next $8 \mathrm{~h}$. This was followed by flattening of the curve and then the second exponential phase after $28 \mathrm{~h}$ (Fig. 2). The growth reached the final stationary phase after $56 \mathrm{~h}$ with biomass of $22.26 \pm 0.98 \mathrm{~g} \mathrm{~L}^{-1}$ (Fig. 2). The initial concentration of the glucose at $0 \mathrm{~h}$ was $50 \mathrm{mg} \mathrm{dL}^{-1}$ which declined gradually to reach zero after $24 \mathrm{~h}$. The second log phase was observed after the glucose was exhausted at $24 \mathrm{~h}$ (Fig. 2). The $B a C D A$ expression starts after $28 \mathrm{~h}$, as $E$. coli cells start lactose consumption and allolactose was produced to induce the expression. The enzyme activity in the culture lysate was observed after $28 \mathrm{~h}$ and reaches $14.05 \pm 0.51 \mathrm{U}$ $\mathrm{mg}^{-1}$ within $44 \mathrm{~h}$ (Fig. 2). The maximum biomass was at 56 th $\mathrm{h}$ and the enzyme activity at this point was found to be $15.01 \pm 0.58 \mathrm{U} \mathrm{mg}^{-1}$. Therefore, $56 \mathrm{~h}$ of culture was used for further expression studies.

\section{BaCDA characterization}

The enzyme velocity of the purified $\mathrm{BaCDA}$ was estimated between 30 and 360 min using EGC and COS as substrates
(Fig. 3A). Maximum enzyme activities of $18.21 \pm 0.25$ $\mathrm{U} \mathrm{mg}^{-1}$ and $36.13 \pm 0.94 \mathrm{U} \mathrm{mg}^{-1}$ were observed at $60 \mathrm{~min}$ with EGC and COS, respectively. After $60 \mathrm{~min}$, the enzyme activity gradually decreased and reached $1.61 \pm 0.07 \mathrm{U} \mathrm{mg}^{-1}$ and $1.86 \pm 0.06 \mathrm{U} \mathrm{mg}^{-1}$ with EGC and COS, respectively (Fig. 3A).

Therefore, further experiments were carried out for one hour. The $\mathrm{pH}$ optima of $\mathrm{BaCDA}$ were studied in the $\mathrm{pH}$ ranges of 4-10. The $\mathrm{BaCDA}$ showed maximum activity at $\mathrm{pH} 7$ in all buffer conditions in both substrates. The enzyme activity was maximum $20.69 \pm 0.20 \mathrm{U} \mathrm{mg}^{-1}$ and $42.99 \pm 0.71 \mathrm{U} \mathrm{mg}^{-1}$ with substrate EGC and COS, respectively, in of $50 \mathrm{mM}$ Tris- $\mathrm{HCl}$ buffer at $\mathrm{pH} 7$ (Fig. 3B and C). An increase or decrease in the $\mathrm{pH}$ results in the loss of enzyme activity in all buffer conditions. Therefore, the optimum buffer and $\mathrm{pH}$ condition were set to $50 \mathrm{mM}$ Tris- $\mathrm{HCl}$ and $\mathrm{pH} 7$, respectively.

The temperature optima were studied in ranges between 20 and $60^{\circ} \mathrm{C}$. The maximum enzyme activity was found to be at $30^{\circ} \mathrm{C}$. The maximum enzyme activity was $29.28 \pm 1.00$ $\mathrm{U} \mathrm{mg}^{-1}$ and $53.47 \pm 2.90 \mathrm{U} \mathrm{mg}^{-1}$ with substrate EGC and COS, respectively, at $30{ }^{\circ} \mathrm{C}$ (Fig. 3D). Further, an increase in the reaction temperature results in activity loss to $18.26 \pm 1.32 \mathrm{U} \mathrm{mg}^{-1}$ and $29.32 \pm 1.19 \mathrm{U} \mathrm{mg}^{-1}$ with substrate EGC and COS, respectively, at $60^{\circ} \mathrm{C}$ (Fig. 3D).
Fig. 2 Expression study in TB lactose-induced media. Glucose concentration $(\mathbf{O})$, cell biomass $(\diamond)$, and enzyme activity $(\boldsymbol{\Delta})$ plotted against time ( $X$-axis). All experiments were performed in triplicates and error bars represent the standard deviation of the mean

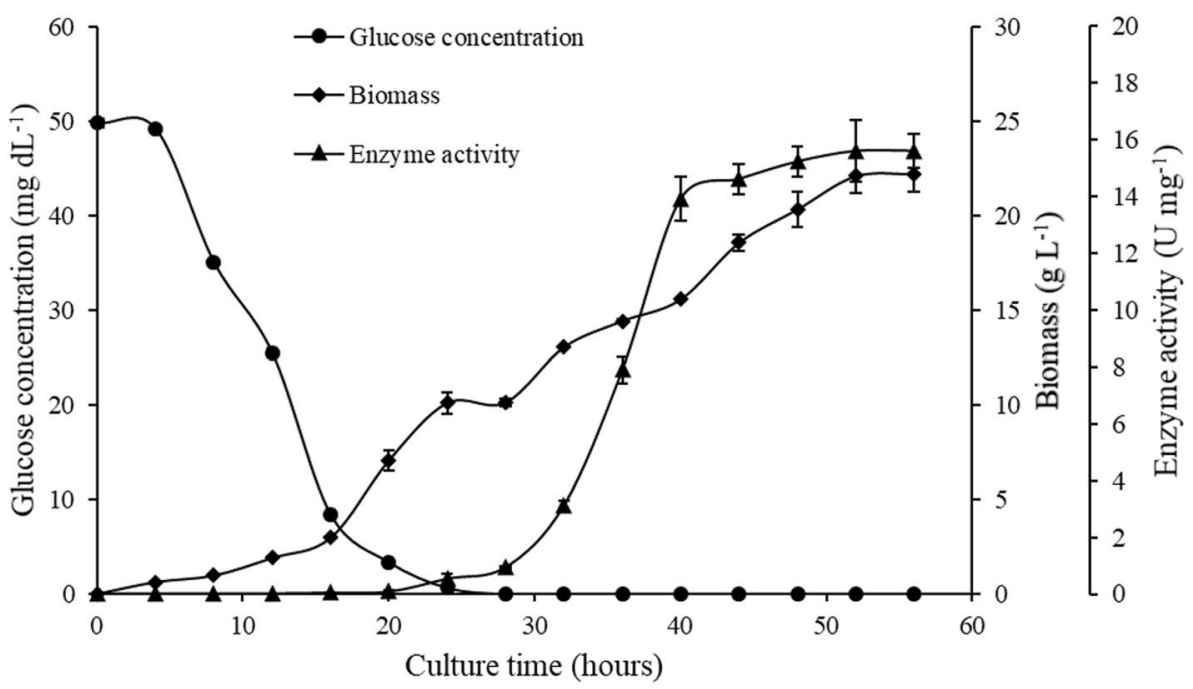


A
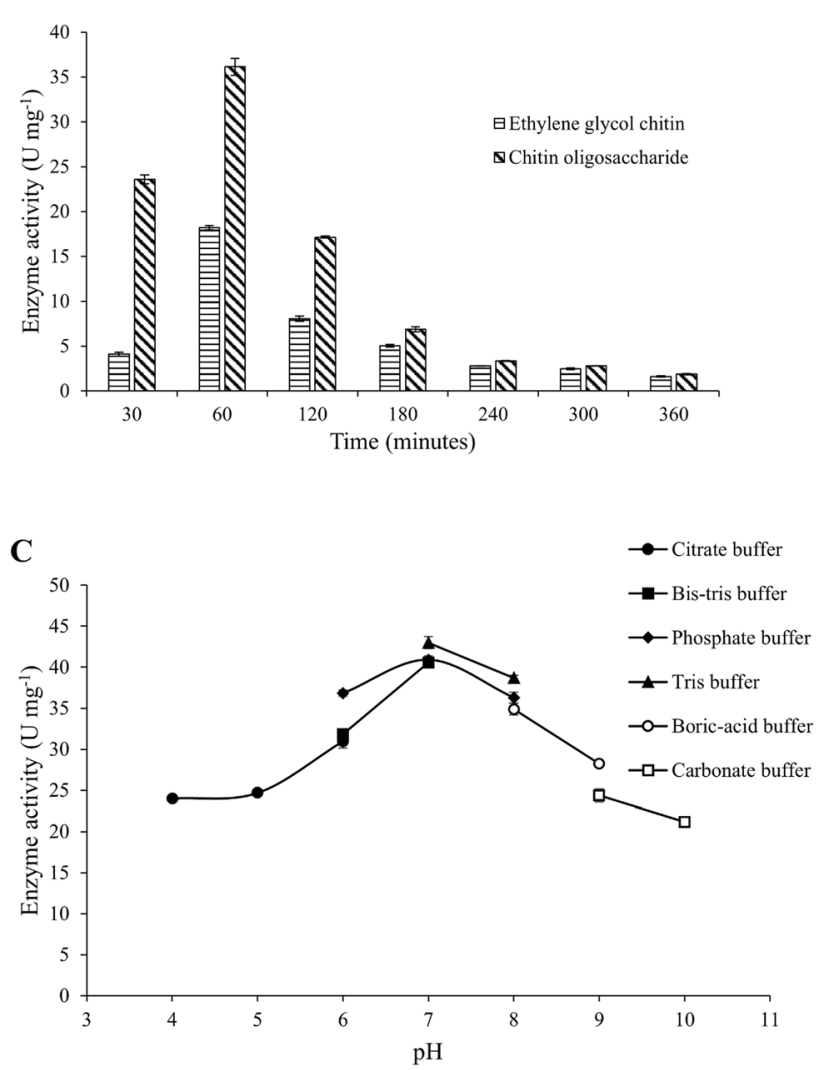

E

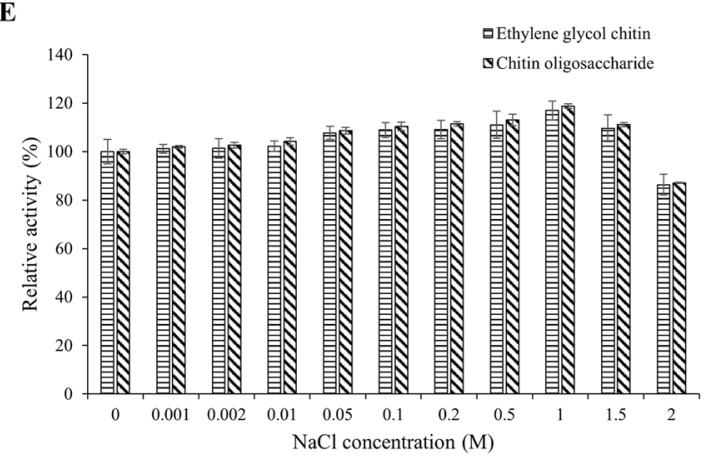

Fig. 3 A Recombinant BaCDA enzyme velocity study. B Recombinant $\mathrm{BaCDA}$ activity in buffer system covering the $\mathrm{pH}$ range 4-10, when EGC was used as substrate. (Citrate buffer-0, Bis-tris buffer $-\mathbf{\square}$, Phosphate buffer $\longrightarrow$, Tris- $\mathrm{HCl}$ buffer- $-\mathbf{\Delta}$, Boric acid buffer- $\mathrm{O}$, Carbonate buffer- $\square$ ). C Recombinant $\mathrm{BaCDA}$ activity in buffer system covering the $\mathrm{pH}$ range $4-10$, when COS was used as substrate. (Citrate buffer-0, Bis-tris buffer- $-\mathbf{n}$, Phosphate buffer- $\longrightarrow$, Tris-HCl buffer- $\boldsymbol{\Lambda}$, Boric acid buffer-O, Carbonate

CDA is known to be metalloenzymes; hence, the effect of the metal co-factors was studied. The effect of metal ions at a concentration of $1 \mathrm{mM}$ on the enzyme activity was assayed. The presence of metal chelators like EDTA was also analysed (Table 2). The inclusion of $1 \mathrm{mM}$ metal ions, such as

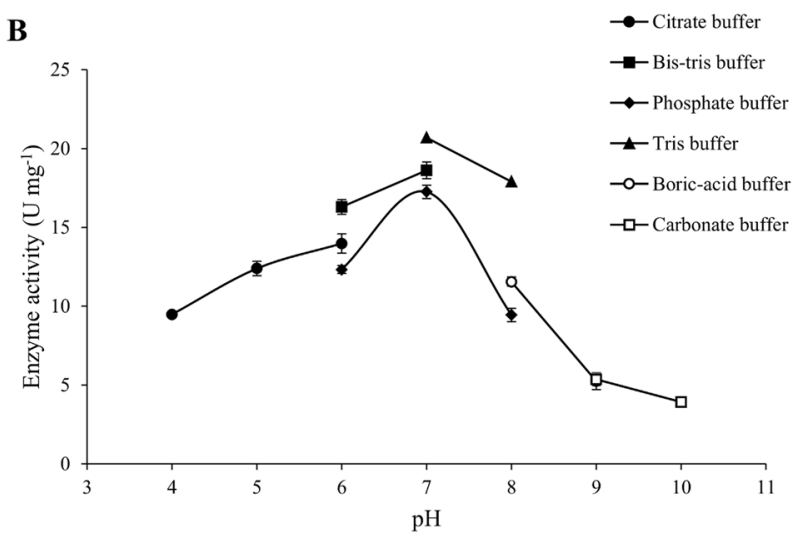

D
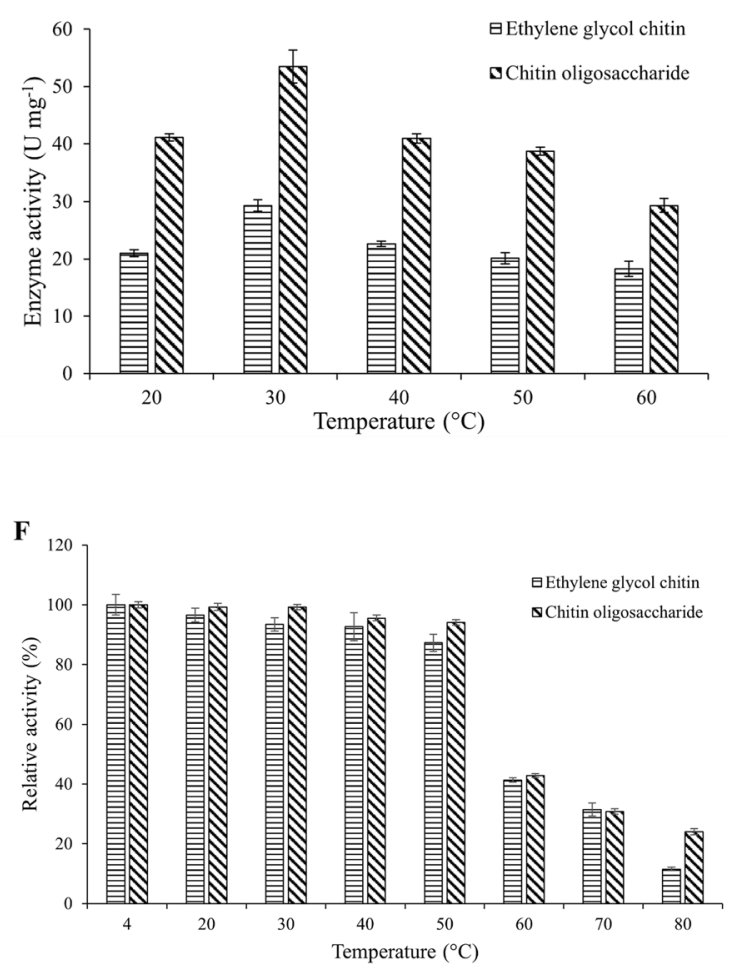

buffer- $\square$ ). D The optimum temperature for $B a C D A$, the enzyme activity was determined at the temperature ranging from 20 to $60^{\circ} \mathrm{C}$. $\mathbf{E}$ The salt tolerance of $B a \mathrm{CDA}$, the enzyme activity was investigated in presence of $\mathrm{NaCl}$ concentration ranging from 0.001 to $2 \mathrm{M}$. F The thermo-stability of $\mathrm{BaCDA}$, the enzyme activity was tested by incubating the enzyme at a different temperature ranging from 4 to $80{ }^{\circ} \mathrm{C}$ for $24 \mathrm{~h}$. All experiments were performed in triplicates and error bars represent the standard deviation of the mean

$\mathrm{K}^{+}, \mathrm{Na}^{+}, \mathrm{Ca}^{2+}, \mathrm{Co}^{2+}, \mathrm{Mn}^{2+}, \mathrm{Mg}^{2+}, \mathrm{Fe}^{2+}, \mathrm{Ni}^{2+}$, and $\mathrm{Zn}^{2+}$, resulted in $89.36 \pm 4.45 \%, 97.95 \pm 7.82 \%, 91.75 \pm 3.96 \%$, $84.67 \pm 4.99 \%, \quad 83.17 \pm 3.30 \%, \quad 132.93 \pm 7.26 \%$, $62.51 \pm 6.03 \%, 58.87 \pm 8.28 \%$, and $68.57 \pm 8.36 \%$ of the original activity, respectively, when EGC was used as substrate 
(Table 2). While with the substrate COS, the $1 \mathrm{mM}$ metal ion $\mathrm{K}^{+}, \mathrm{Na}^{+}, \mathrm{Ca}^{2+}, \mathrm{Co}^{2+}, \mathrm{Mn}^{2+}, \mathrm{Mg}^{2+}, \mathrm{Fe}^{2+}, \mathrm{Ni}^{2+}$, and $\mathrm{Zn}^{2+}$ resulted in $84.94 \pm 5.94 \%, 98.24 \pm 5.23 \%, 93.98 \pm 6.00 \%$, $87.53 \pm 3.54 \%, \quad 85.22 \pm 2.90 \%, \quad 135.34 \pm 3.26 \%$, $69.04 \pm 5.82 \%, 54.74 \pm 8.37 \%$, and $67.18 \pm 5.02 \%$ of the original activity, respectively. When $1 \mathrm{mM}$ EDTA was added to the enzymatic reaction, $40.83 \pm 5.71 \%$ and $48.83 \pm 2.70 \%$ of the original enzymatic activity were retained with the substrate EGC and COS respectively (Table 2). Acetate is one of the by-products of the chitin deacetylase reaction and caused feedback inhibition. Hence, the inhibitory action of acetate ion on the enzyme activity was studied at a concentration range of 0.1 to $10 \mathrm{mM}$. An increasing trend of inhibition was observed with an increase of acetate from 0.1 to $10 \mathrm{mM}$. The maximum inhibition was $49.88 \pm 3.89 \%$ and $46.95 \pm 2.43 \%$ in presence of $10 \mathrm{mM}$ of acetate was observed with the substrate EGC and COS respectively (Table 2). A titration of the $\mathrm{Mg}^{2+}$ was made in the standard assay conditions. An increase of $\mathrm{Mg}^{2+}$ concentration from 0.5 to $1.5 \mathrm{mM}$ resulted in a $137.43 \pm 4.74 \%$ and $139.22 \pm 3.99 \%$ increased activity with EGC and COS, respectively. This further incremented to $142.43 \pm 7.13 \%$ and $146.88 \pm 4.09 \%$ with EGC and COS, respectively, in presence of $2 \mathrm{mM}$ $\mathrm{Mg}^{2+}$. Further increase of $\mathrm{Mg}^{2+}$ concentration resulted in a

Table 2 Effect of metal co-factors on $\mathrm{BaCDA}$ enzyme activity

\begin{tabular}{|c|c|c|c|}
\hline \multirow[t]{2}{*}{ Metal ion } & \multirow[t]{2}{*}{ Concentration } & \multicolumn{2}{|c|}{ Relative activity (\%) } \\
\hline & & $\begin{array}{l}\text { Ethylene glycol } \\
\text { chitin }\end{array}$ & $\begin{array}{l}\text { Chitin oligo- } \\
\text { saccharide }\end{array}$ \\
\hline Control & - & $100 \pm 11.23$ & $100.00 \pm 5.82$ \\
\hline $\mathrm{K}^{+}$ & $1 \mathrm{mM}$ & $89.36 \pm 4.45$ & $84.94 \pm 5.94$ \\
\hline $\mathrm{Na}^{+}$ & $1 \mathrm{mM}$ & $97.95 \pm 7.82$ & $98.24 \pm 5.23$ \\
\hline $\mathrm{Ca}^{2+}$ & $1 \mathrm{mM}$ & $91.75 \pm 3.96$ & $93.98 \pm 6.00$ \\
\hline $\mathrm{Co}^{2+}$ & $1 \mathrm{mM}$ & $84.67 \pm 4.99$ & $87.53 \pm 3.54$ \\
\hline $\mathrm{Mn}^{2+}$ & $1 \mathrm{mM}$ & $83.17 \pm 3.30$ & $85.22 \pm 2.90$ \\
\hline $\mathrm{Fe}^{2+}$ & $1 \mathrm{mM}$ & $62.51 \pm 6.03$ & $69.04 \pm 5.82$ \\
\hline $\mathrm{Ni}^{2+}$ & $1 \mathrm{mM}$ & $58.87 \pm 8.28$ & $54.74 \pm 8.37$ \\
\hline $\mathrm{Zn}^{2+}$ & $1 \mathrm{mM}$ & $68.57 \pm 8.36$ & $67.18 \pm 5.02$ \\
\hline EDTA & $1 \mathrm{mM}$ & $40.83 \pm 5.71$ & $48.83 \pm 2.70$ \\
\hline \multirow[t]{3}{*}{ Acetate } & $0.1 \mathrm{mM}$ & $96.75 \pm 7.84$ & $94.34 \pm 5.01$ \\
\hline & $1 \mathrm{mM}$ & $92.77 \pm 3.32$ & $82.16 \pm 1.40$ \\
\hline & $10 \mathrm{mM}$ & $49.88 \pm 3.89$ & $46.95 \pm 2.43$ \\
\hline \multirow[t]{6}{*}{$\mathrm{Mg}^{2+}$} & $0.5 \mathrm{mM}$ & $110.49 \pm 8.81$ & $125.16 \pm 3.64$ \\
\hline & $1 \mathrm{mM}$ & $132.93 \pm 7.26$ & $135.34 \pm 3.26$ \\
\hline & $1.5 \mathrm{mM}$ & $137.43 \pm 4.74$ & $139.22 \pm 3.99$ \\
\hline & $2 \mathrm{mM}$ & $142.43 \pm 7.13$ & $146.88 \pm 4.09$ \\
\hline & $2.5 \mathrm{mM}$ & $141.32 \pm 7.40$ & $143.85 \pm 3.32$ \\
\hline & $3 \mathrm{mM}$ & $141.50 \pm 7.95$ & $143.64 \pm 0.19$ \\
\hline
\end{tabular}

The effect of metal ions was investigated taking a reaction without any metal ion as control. The values correspond to the average and standard deviation of experiments done in triplicates decreased activity (Table 2). Hence, $2 \mathrm{mM} \mathrm{Mg}^{2+}$ was used for further experiments.

In the study, to evaluate the salt tolerance of $\mathrm{BaCDA}$, the enzyme activity without $\mathrm{NaCl}$ was considered as $100 \%$. The relative enzyme activity increased with an increment in $\mathrm{NaCl}$ concentration and was found maximum in presence of $1 \mathrm{M} \mathrm{NaCl}$. The relative activity detected with $1 \mathrm{M} \mathrm{NaCl}$ was $116.98 \pm 3.87 \%$ and $118.70 \pm 0.98 \%$ for EGC and COS, respectively (Fig. 3E). Further increase in the salt concentration to $2 \mathrm{M}$ led to a decrease in the activity $(86.27 \pm 4.33 \%$ and $87.08 \pm 0.21 \%$ for EGC and COS, respectively). The thermo-stability of the enzyme was determined by incubating the enzyme at a different temperature ranging from 4 to $80{ }^{\circ} \mathrm{C}$ in presence of $2 \mathrm{mM} \mathrm{Mg}^{2+}$ and $1 \mathrm{M} \mathrm{NaCl}$ for $24 \mathrm{~h}$ at a steady state. The enzyme stored at $4{ }^{\circ} \mathrm{C}$ was considered as $100 \%$ enzyme activity. The enzyme was stable up to $50{ }^{\circ} \mathrm{C}$ with less significant loss of activity $(87.27 \pm 2.85 \%$ and $94.08 \pm 0.92 \%$ for EGC and COS, respectively). However, the enzyme activity decreased significantly on increasing the temperature to $60{ }^{\circ} \mathrm{C}$. The relative enzyme activity on incubating at $60{ }^{\circ} \mathrm{C}$ was $41.35 \pm 0.66 \%$ and $42.86 \pm 0.60 \%$ with EGC and COS, respectively (Fig. 3F).

\section{Kinetic parameter studies of $\mathrm{BaCDA}$}

The kinetic parameters of recombinant $\mathrm{BaCDA}$ were performed with EGC at concentrations from 1.00 to $5.00 \mathrm{E}-7 \mu \mathrm{g} \mathrm{mL}{ }^{-1}$ and estimated with acetate released during the reaction. The kinetics of the enzyme showed an excellent fit to the Michaelis-Menten equation (Fig. 4A). The $K_{\mathrm{m}}$ value of $\mathrm{BaCDA}$ was $3.06 \mathrm{E}-05 \mu \mathrm{g} \mathrm{mL} \mathrm{m}^{-1}$, and the maximal velocity was $3.06 \mathrm{E}+01 \mu \mathrm{M} \mathrm{mg}{ }^{-1} \mathrm{~min}^{-1}$. The turnover number and the catalytic efficiency value were $3.27 \mathrm{E}+04 \mathrm{~s}^{-1}$ and $1.07 \mathrm{E}+09 \mu \mathrm{g}^{-1} \mathrm{~mL}^{-1} \mathrm{~s}^{-1}$, respectively, according to the $K_{\mathrm{m}}$ and $V_{\max }$ (Table 3 ).

The kinetic parameters of recombinant $\mathrm{BaCDA}$ were performed with $\mathrm{COS}$ at concentrations from 1.00 to $1.00 \mathrm{E}-8 \mu \mathrm{g} \mathrm{mL}^{-1}$ and estimated with acetate released during the reaction. The kinetics of the enzyme showed an excellent fit to the Michaelis-Menten equation (Fig. 4B). The $K_{\mathrm{m}}$ value of $B a C D A$ was $7.14 \mathrm{E}-07 \mu \mathrm{gL}^{-1}$, and the maximal velocity was $7.14 \mathrm{E}+01 \mu \mathrm{M} \mathrm{mg}{ }^{-1} \mathrm{~min}^{-1}$. The turnover number and the catalytic efficiency value were $1.40 \mathrm{E}+06 \mathrm{~s}^{-1}$ and $1.96 \mathrm{E}+12 \mu \mathrm{g}^{-1} \mathrm{~mL}^{-1} \mathrm{~s}^{-1}$, respectively, according to the $K_{\mathrm{m}}$ and $V_{\max }$ (Table 3 ).

\section{Discussion}

Seafood waste processing generates chitin, an undervalued waste. Despite being a second-abundant biopolymer, the applications are limited due to their crystalline nature. This limitation can be addressed by converting chitin to 
Fig. 4 A Michaelis-Menten kinetic curve generated using EGC as a substrate. B Michaelis-Menten kinetic curve generated using COS as a substrate. All experiments were performed in triplicates and error bars represent the standard deviation of the mean
Table 3 Kinetic parameters of Chitin deacetylase from $B$. aryabhattai, EGC, and COS were taken as a substrate
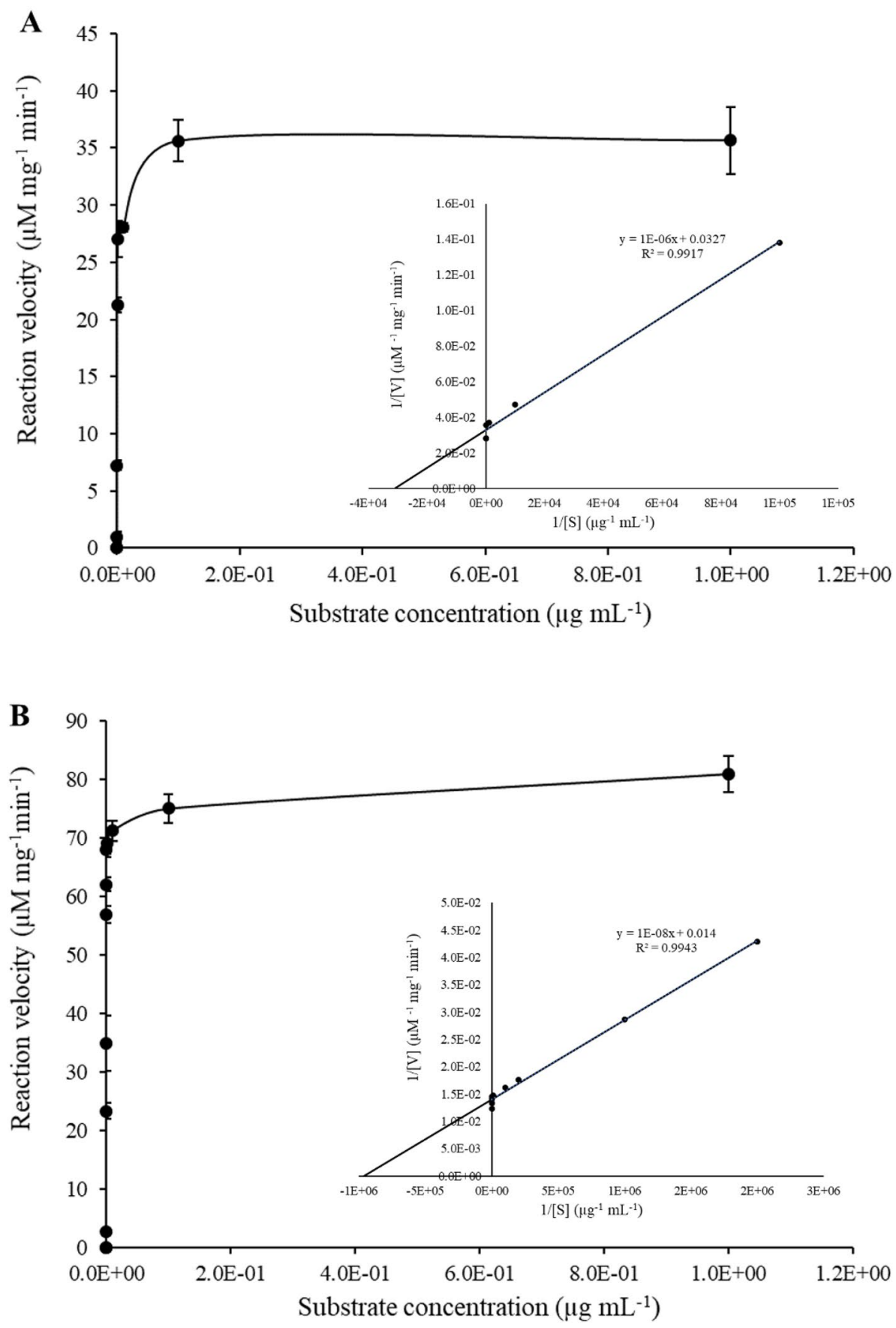

The values correspond to the average and standard deviation of experiments done in triplicates

\begin{tabular}{lllll}
\hline Substrate & $K_{\mathrm{m}}\left(\mu \mathrm{g} \mathrm{mL} \mathrm{m}^{-1}\right)$ & $\begin{array}{l}V_{\mathrm{max}}(\mu \mathrm{M} \\
\left.\mathrm{mg}^{-1} \mathrm{~min}^{-1}\right)\end{array}$ & $K_{\mathrm{cat}}\left(\mathrm{s}^{-1}\right)$ & $\begin{array}{l}K_{\mathrm{cat}} / K_{\mathrm{m}} \\
\left(\mu \mathrm{gg}^{-1} \mathrm{~mL}^{-1} \mathrm{~s}^{-1}\right)\end{array}$ \\
\hline $\begin{array}{l}\text { Ethylene glycol chitin } \\
\text { Chitin oligosaccharides }\end{array}$ & $3.06 \mathrm{E}-05$ & $3.06 \mathrm{E}+01$ & $3.27 \mathrm{E}+04$ & $1.07 \mathrm{E}+09$ \\
\hline
\end{tabular}


chitosan (Yadav et al. 2019). To date, the commercial production of chitosan is carried out through chemical deacetylation which results in a random pattern of deacetylation and the chemicals used for this conversion are hazardous to the environment (Santos et al. 2020). The greener route for the conversion is using enzymes like CDA. As marine is the major source for chitin, it also upholds the enzymes converting it to chitosan (Younes and Rinaudo 2015). The reports on CDA-producing bacteria are sparse. Vibrio species and Nitratireductor aquimarinus are the only species reported from the marine environment. Thus, the marine bacterial ecosystem as a source of CDA can be widely explored (Ghormade et al. 2010).

In the present study, we have isolated 15 bacteria from $40 \mathrm{~m}$ sea sediment with $12^{\circ} 48^{\prime} \mathrm{N}$ and $74^{\circ} 40^{\prime} \mathrm{E}$ as the coordinates. The isolates were screened on a receptorbased screening plate and out of fifteen, four isolates were having CDA activity (Pawaskar et al. 2019). The reason for the growth of other organisms on the colloidal chitin plate could be due to the production of other chitinolytic enzymes (Patel et al. 2007; Kaczmarek et al. 2019; Schmitz et al. 2019; Mathew et al. 2021). The CDA production of all the four isolates was quantitated by the spectrophotometric-based method and isolate MS7 yielded the maximum CDA activity. The 16S rRNA gene of the isolate MS7 had a 99\% match with B. aryabhattai B8W22. The first mention of B.aryabhattai was in the report by Shivaji et al. where they had isolated the strain from atmospheric air using cryotubes at an altitude of $27-30 \mathrm{~km}$ (Shivaji et al. 2009). The second mention of B. aryabhattai was in the work of Semanti Ray et al. where they report the extra-terrestrial microorganism to be found in the Indian Sub-continent, evidence in support of the Theory of Panspermia. In continuation of proving the Theory of Panspermia, we report the isolation of $B$. aryabhattai from Arabian Sea sediment at a depth of $40 \mathrm{~m}$ depth. The microorganisms were isolated under high salt conditions by providing synthetic seawater and thus, all the isolates were halophilic (Dalmaso et al. 2015). The CDA gene in the $B$. aryabhattai genome was identified by a homologybased method using the putative CDA gene from $B$. megaterium. The identified $B a C D A$ gene was annotated in the NCBI gene databank, available in the third-party section of the DDBJ/ENA/GenBank databases under the accession number TPA: BK010747 for the BaCDA gene. The annotated $B a C D A$ gene $(\sim 765 \mathrm{bp})$ was cloned in the pET-22b $(+)$ vector and overexpressed in $E$. coli Rosetta pLysS cells to overexpress a $29 \mathrm{kDa}$ enzyme. The molecular weight of $\mathrm{CDA}$ as reported from various sources range between 25 and $80 \mathrm{kDa}$ (Ghormade et al. 2010; Zhao et al. 2010). The temperature of induction was an important criterion, and the optimization experiments were conducted at two temperatures viz $37{ }^{\circ} \mathrm{C}$ and $16{ }^{\circ} \mathrm{C}$. At $37^{\circ} \mathrm{C}$, the expression of CDA as inclusion bodies. This has been supported by a similar finding wherein lower temperatures after induction help in the proper folding of the protein in E. coli (Rosano and Ceccarelli 2014). Hence, further expression studies were performed at $16{ }^{\circ} \mathrm{C}$.

In the T7 lac promoter vector systems, IPTG can be replaced by lactose as an inducer. The inclusion of lactose not only reduces the overall cost of the process, but also reduces the toxicity caused to the host (Blommel et al. 2007). Hence, in the present study, the inducer optimization was also performed based on literature reports. The media with lactose were designated as auto-induction (AI) media. The induction in AI media was controlled with the inclusion of glucose as a component. To obtain the maximum expression level with IPTG induction and lactose induction, the three commonly used media viz. LB, 2YT, and TB media were used. The expression and the cell density were highest in TB lactose induction media as compared to the other combinations of media studied. This could be due to the inclusion of glycerol in the media. Glycerol when coupled with glucose and lactose in the culture media was known to positively impact recombinant protein production (Blommel et al. 2007). The TB lactose induction medium was optimized for $B a C D A$ expression, and the obtained protein was purified by Ni-NTA affinity chromatography. We could obtain the purified $B a \mathrm{CDA}$ to homogeneity with the single-step purification protocol. The purified $B a C D A$ had an estimated molecular mass of $29 \mathrm{kDa}$ as observed in the $12.5 \%$ SDS-PAGE. The $B a C D A$ expression was scaled up to $1 \mathrm{~L} \mathrm{~TB}$ lactose induction media. Catabolite repression was observed in the presence of glucose as it was readily metabolized by the cell and thus prevented the uptake of lactose. Similar findings have also been observed by other authors (Kopp et al. 2018). The availability of glucose was exhausted after $24 \mathrm{~h}$; this led to the uptake of lactose by the cells. Lactose upon conversion to allo-lactose led to the induction of the T7 lac promoter present in the pET-22b (+) vector. Hence, the $B a C D A$ expression upregulated after the 28th h of growth. Glycerol present in the TB media does not result in catabolite repression; hence, higher expression yields were obtained in TB lactose induction media as compared to LB and 2YT lactose induction media. This is in agreement with the findings by other authors (Studier 2005; Blommel et al. 2007; Kopp et al. 2018).

To date, reported bacterial CDAs were active on either chitin polymer or chitin oligosaccharides. Only a few fungal CDAs are reported for activity on substrates with a wide range of DP (Kaczmarek et al. 2019). The purified $B a C D A$ reported in this study was active on both EGC and COS. Therefore, characterization of $\mathrm{BaCDA}$ was done using ethylene glycol chitin as well as chitin oligosaccharides. Before initiating the $\mathrm{pH}$ and temperature characterization of $B a C D A$, we investigated the initial velocity 
required by the enzyme to convert EGC and COS. We found that the conversion rate was faster in the initial phase leading to a decrease in the peak after $60 \mathrm{~min}$ of incubation. A similar finding was also observed by Win and Stevens with fungal Absidia coerulea CDA (Win and Stevens 2001). This decrease could be due to the build-up of acetate as the by-product of the deacetylation reaction which has been reported to result in feedback inhibition (Zhao et al. 2010). A similar inhibitory effect of acetate on CDA has also been reported in Absidia orchidis vel coerulea, Amylomyces rouxii, Lichtheimia corymbifera, Penicillium oxalicum, Rhizomucor miehei, and Saccharomyces cerevisiae (Ghormade et al. 2010). In the present study, $B a \mathrm{CDA}$ enzyme activity was found to be maximum with a $50 \mathrm{mM}$ Tris- $\mathrm{HCl}$ buffer at a $\mathrm{pH}$ of 7 , and the optimum temperature was found to be $30^{\circ} \mathrm{C}$. This was in agreement with the $\mathrm{pH}$ ranges found in the microbial CDA where groups have reported the $\mathrm{pH}$ optima ranging from 4.5 to 12 (Grifoll-Romero et al. 2018). BaCDA displayed a wide range of $\mathrm{pH}$ tolerance with effective conversion in both the acidic and the alkaline range with the maxima at $\mathrm{pH}$ 7. Nitratireductor aquimarinus, the recently characterized marine bacteria has the $\mathrm{pH}$ optima at 8 and temperature maxima at $30{ }^{\circ} \mathrm{C}$ (Chai et al. 2020). CDA is known to be metalloenzymes and thus becomes activated with divalent metal co-factors. In the present study, divalent ion $\mathrm{Mg}^{2+}$ at the concentration of $2 \mathrm{mM}$ led to an enhancement in the enzyme activity. For most of the CDA reported, $\mathrm{Co}^{2+}$ acts as an activator/enhancer (Ghormade et al. 2010). $\mathrm{Mg}^{2+}$ as a co-factor has been reported in CDA activity obtained from B. amyloliquefaciens, Lichtheimia corymbifera, Penicillium oxalicum, and Rhizopus circinans organisms (Grifoll-Romero et al. 2018). On the other hand, $\mathrm{Sr}^{2+}$ was the activator in CDA reported in Nitratireductor aquimarinus (Chai et al. 2020). In the present study, EDTA with a concentration of $1 \mathrm{mM}$ inhibited the enzyme activity to $40.83 \pm 5.71 \%$ and $48.83 \pm 2.70 \%$ when EGC and COS were used as substrate, respectively, which was higher than its marine counterpart Nitratireductor aquimarinus, which reported a loss of $70 \%$ enzymatic activity (Chai et al. 2020). The enzyme physio-chemical properties are mainly due to the source of the enzyme. As the $B a C D A$ gene was amplified from $B$. aryabhattai $\mathrm{B} 8 \mathrm{~W} 22$, a marine isolate, it was expected to be halotolerant and thermostable (Jin et al. 2019). The enzyme displayed an improved activity with the inclusion of $1 \mathrm{M} \mathrm{NaCl}$ in the assay solution. The $\mathrm{BaCDA}$ was thermostable up to $50{ }^{\circ} \mathrm{C}$ for $24 \mathrm{~h}$. Above $50^{\circ} \mathrm{C}, \mathrm{BaCDA}$ enzyme activity decreases significantly on incubating for $24 \mathrm{~h}$. In recent years, use for extremozyme showed potential for industrial application due to the ease of biotechnological processes (Dumorné et al. 2017). There are several studies on extremozymes for their industrial application with few chitinolytic enzymes too reported (Niehaus et al. 1999; Wang et al. 2016; Paranetharan et al. 2018). There are reports on thermostable chitin deacetylase (Grifoll-Romero et al. 2018). However, no reports on exploring the salt-tolerant CDA were found. The halotolerant and thermo-stability property of $\mathrm{BaCDA}$ makes it novel with high industrial applicability.

The kinetic parameters for $\mathrm{BaCDA}$ on EGC and COS were obtained from the Lineweaver-Burk plot analysis and the enzyme reaction rates seemed to follow the Michaelis-Menten kinetics. The kinetic parameters of $B a C D A$ can be compared with other reported CDAs. The CDA from $B$. amyloliquefaciens having the $K_{\mathrm{m}}$ of $9.96 \mathrm{E}-06 \mu \mathrm{g} \mathrm{mL} \mathrm{L}^{-1}$, $V_{\max }$ of $4.78 \mathrm{E}+06 \mu \mathrm{M} \mathrm{min}{ }^{-1}$, and $K_{\text {cat }}$ of $5.18 \mathrm{E}+03 \mathrm{~s}^{-1}$ under optimum conditions (Bhat et al. 2019). The kinetic parameters with the fungal CDA from Colletotrichum lindemuthianum on EGC have reported the $K_{\mathrm{m}}, V_{\text {max }}$ and $K_{\text {cat }}$ of $2.55 \mathrm{mM}, 51.3 \mu \mathrm{M} \mathrm{mg} \mathrm{min}^{-1}$ and $27.1 \mathrm{~s}^{-1}$, respectively (Tokuyasu et al. 1996). The other fungal CDA studied on EGC was Aspergillus nidulans where $K_{\mathrm{m}}$ of $4.92 \mathrm{E}+03 \mu \mathrm{g} \mathrm{mL}^{-1}, V_{\max }$ was $0.77 \mu \mathrm{M} \mathrm{mg}^{-1} \mathrm{~min}^{-1}$ and $K_{\text {cat }}$ of $6.25 \mathrm{~s}^{-1}$ have been reported (Wang et al. 2010). These results help us to conclude that the $B a C D A$ has a more affinity than that of fungal CDA but less affinity than that of recombinant CDA from B. amyloliquefaciens when EGC was used as substrate. To date, only fungal CDAs are reported for activity towards COS. $B a C D A$ is the first bacterial recombinant CDA reporting for activity towards EGC as well as COS.

In conclusion, the marine environment can be explored to find novel extremophilic microorganisms producing extremozyme CDAs. The products obtained after enzymatic modification yield specific deacetylation fingerprints. This makes them a better choice for biomedical applications (Morin-Crini et al. 2019). The use of extremozyme leads to reduce the operational cost, risk of contamination during the process, and due to the stability, high productivity is also obtained (Dumorné et al. 2017; Jin et al. 2019). Thus, $\mathrm{BaCDA}$ being the extremozyme, could be used for the industrial production of enzymatically derived chitosan polymer as well as chitosan oligosaccharides with the known pattern of deacetylation. Even though the $\mathrm{K}_{\mathrm{m}}$ and $\mathrm{V}_{\max }$ values showed good affinity towards the substrates EGC as well as $\mathrm{COS}$, it was observed that the $\mathrm{BaCDA}$ had more affinity towards COS because of the short length of the substrate. Therefore, $\mathrm{BaCDA}$ could be used as chitin oligosaccharide deacetylase as well as chitin deacetylase.

Supplementary Information The online version contains supplementary material available at https://doi.org/10.1007/s13205-021-03073-3.

Acknowledgements The authors would like to thank Manipal Academy for Higher Education (MAHE), Manipal for the MAHE UNSW fund and CSIR-MHRD for a senior research fellowship, award

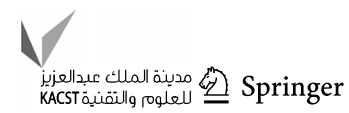


letter-number 09/1165(0007)2K19 EMR-I dated on 31.3.2019. They would also like to thank NITK, Surathkal for the internal resource funding.

Author contributions RR has been conceptualized, supervised, investigated, administrated the project and edited the manuscript. GMP has performed, analysed and written the manuscript. KR has investigated, reviewed and edited the manuscript. PR has helped with resources. RPS has performed the formal analysis. All authors have read and approved the final manuscript.

Funding Open access funding provided by Manipal Academy of Higher Education, Manipal.

\section{Declarations}

Conflict of interest The authors declare that they have no conflict of interest in the publication.

Open Access This article is licensed under a Creative Commons Attribution 4.0 International License, which permits use, sharing, adaptation, distribution and reproduction in any medium or format, as long as you give appropriate credit to the original author(s) and the source, provide a link to the Creative Commons licence, and indicate if changes were made. The images or other third party material in this article are included in the article's Creative Commons licence, unless indicated otherwise in a credit line to the material. If material is not included in the article's Creative Commons licence and your intended use is not permitted by statutory regulation or exceeds the permitted use, you will need to obtain permission directly from the copyright holder. To view a copy of this licence, visit http://creativecommons.org/licenses/by/4.0/.

\section{References}

Anas A, Nilayangod C, Jasmin C, Vinothkumar S, Parameswaran PS, Nair S (2016) Diversity and bioactive potentials of culturable heterotrophic bacteria from the surficial sediments of the Arabian Sea. 3Biotech 6:238. https://doi.org/10.1007/ s13205-016-0556-x

Andreou LV (2013) Preparation of genomic DNA from bacteria. Methods Enzymol 529:143-151. https://doi.org/10.1016/B9780-12-418687-3.00011-2

Andreou A, Giastas P, Christoforides E, Eliopoulos EE (2018) Structural and evolutionary insights within the polysaccharide deacetylase gene family of bacillus anthracis and bacillus cereus. Genes (basel) 9:386. https://doi.org/10.3390/genes 9080386

Araki Y, Ito E (1988) Chitin deacetylase. Methods Enzymol 161:510-514. https://doi.org/10.1016/0076-6879(88)61068-8

Bhat P, Pawaskar GM, Raval R, Cord-Landwehr S, Moerschbacher B, Raval K (2019) Expression of Bacillus licheniformis chitin deacetylase in E. coli pLysS: sustainable production, purification and characterization. Int J Biol Macromol 131:1008-1013. https://doi.org/10.1016/j.ijbiomac.2019.03.144

Blommel PG, Becker KJ, Duvnjak P, Fox BG (2007) Enhanced bacterial protein expression during auto-induction obtained by alteration of lac repressor dosage and medium composition. Biotechnol Prog 23:585-598. https://doi.org/10.1021/bp070011x

Chai J, Hang J, Zhang C, Yang J, Wang S, Liu S, Fang Y (2020) Purification and characterization of chitin deacetylase active on insoluble chitin from Nitratireductor aquimarinus MCDA3-3.
Int J Biol Macromol 152:922-929. https://doi.org/10.1016/j. ijbiomac.2020.02.308

Cord-Landwehr S, Richter C, Wattjes J, Sreekumar S, Singh R, Basa S, El Gueddari NE, Moerschbacher BM (2020) Patterns matter part 2: chitosan oligomers with defined patterns of acetylation. React Funct Polym 151:104577. https://doi.org/10.1016/j.react functpolym.2020.104577

Dalmaso GZL, Ferreira D, Vermelho AB (2015) Marine extremophiles a source of hydrolases for biotechnological applications. Mar Drugs 13:1925-1965. https://doi.org/10.3390/md13041925

Dumorné K, Córdova DC, Astorga-Eló M, Renganathan P (2017) Extremozymes: a potential source for industrial applications. J Microbiol Biotechnol 27:649-659. https://doi.org/10.4014/jmb. 1611.11006

Ghormade V, Kulkarni S, Doiphode N, Rajamohanan PR, Deshpande MV (2010) Chitin deacetylase: a comprehensive account on its role in nature and its biotechnological applications. Curr Res Technol Educ Top Appl Microbiol Microb Biotechnol 1:1054-1066

Grifoll-Romero L, Pascual S, Aragunde H, Biarnés X, Planas A (2018) Chitin deacetylases: structures, specificities, and biotech applications. Polymers (basel) 10:1-29. https://doi.org/10.3390/polym 10040352

Hall T, Biosciences I, Carlsbad C (2011) BioEdit: an important software for molecular biology. GERF Bull Biosci 2:60-61

Hu B, Guo Y, Li H, Liu X, Fu Y, Ding F (2021) Recent advances in chitosan-based layer-by-layer biomaterials and their biomedical applications. Carbohydr Polym 271:118427. https://doi.org/10. 1016/j.carbpol.2021.118427

Jin M, Gai Y, Guo X, Hou Y, Zeng R (2019) Properties and applications of extremozymes from deep-sea extremophilic microorganisms: a mini-review. Mar Drugs 17:656. https://doi.org/10.3390/ md17120656

Kaczmarek MB, Struszczyk-Swita K, Li X, Szczęsna-Antczak M, Daroch M (2019) Enzymatic modifications of chitin, chitosan, and chitooligosaccharides. Front Bioeng Biotechnol 7:243. https:// doi.org/10.3389/fbioe.2019.00243

Kim M, Chun J (2014) 16S rRNA gene-based identification of bacteria and archaea using the EzTaxon server. Methods Microbiol 41:61-74. https://doi.org/10.1016/bs.mim.2014.08.001

Kopp J, Slouka C, Ulonska S, Kager J, Fricke J, Spadiut O, Herwig C (2018) Impact of glycerol as carbon source onto specific sugar and inducer uptake rates and inclusion body productivity in $E$. coli BL21(DE3). Bioengineering 5:15. https://doi.org/10.3390/ bioengineering 5010001

Kumar S, Stecher G, Li M, Knyaz C, Tamura K (2018) MEGA X: molecular evolutionary genetics analysis across computing platforms. Mol Biol Evol 35:1547-1549. https://doi.org/10.1093/ molbev/msy096

Lineweaver H, Burk D (1934) The determination of enzyme dissociation constants. J Am Chem Soc 56:658-666. https://doi.org/10. 1021/ja01318a036

Lombard V, Golaconda Ramulu H, Drula E, Coutinho PM, Henrissat B (2014) The carbohydrate-active enzymes database (CAZy) in 2013. Nucleic Acids Res. https://doi.org/10.1093/nar/gkt1178

Mathew GM, Huang CC, Sindhu R, Binod P, Sirohi R, Awsathi MK, Pillai S, Pandey A (2021) Enzymatic approaches in the bioprocessing of shellfish wastes. 3Biotech 11:1-13. https://doi.org/ 10.1007/s13205-021-02912-7

Mathivanan A, Ravikumar S, Selvakumar G, Devanandh K (2021) Utilization of Shrimp waste as a novel media for marine bacteria isolation. 3Biotech 11:18. https://doi.org/10.1007/ s13205-020-02564-z

Morin-Crini N, Lichtfouse E, Torri G, Crini G (2019) Applications of chitosan in food, pharmaceuticals, medicine, cosmetics, agriculture, textiles, pulp and paper, biotechnology, and environmental 
chemistry. Environ Chem Lett 17:1667-1692. https://doi.org/10. 1007/s10311-019-00904-X

Niehaus F, Bertoldo C, Kähler M, Antranikian G (1999) Extremophiles as a source of novel enzymes for industrial application. Appl Microbiol Biotechnol 51:711-729. https://doi.org/10.1007/ s002530051456

Paranetharan MS, Thirunavukkarasu N, Rajamani T, Murali TS, Suryanarayanan TS (2018) Salt-tolerant chitin and chitosan modifying enzymes from Talaromyces stipitatus, a mangrove endophyte. Mycosphere 9:215-226. https://doi.org/10.5943/mycos phere $/ 9 / 2 / 5$

Patel B, Gohel V, Raol B (2007) Statistical optimization of medium components for chitinase production by Paenibacillus sabina strain JD2. Ann Microbiol 57:589-597. https://doi.org/10.1007/ BF03175360

Pawaskar GM, Pangannaya S, Raval K, Trivedi DR, Raval R (2019) Screening of chitin deacetylase producing microbes from marine source using a novel receptor on agar plate. Int J Biol Macromol 131:716-720. https://doi.org/10.1016/j.ijbiomac.2019.03.118

Raval R, Raval K, Moerschbacher BM (2013) Enzymatic modification of chitosan using chitin deacetylase isolated from Bacillus cereus. Open Access Sci Rep 2:2-5. https://doi.org/10.4172/scien tificreports.617

Raval R, Simsa R, Raval K (2017) Expression studies of Bacillus licheniformis chitin deacetylase in E. coli Rosetta cells. Int J Biol Macromol 104:1692-1696. https://doi.org/10.1016/j.ijbiomac. 2017.01.151

Robert X, Gouet P (2014) Deciphering key features in protein structures with the new ENDscript server. Nucleic Acids Res 42:1-2. https://doi.org/10.1093/nar/gku316

Rosano GL, Ceccarelli EA (2014) Recombinant protein expression in Escherichia coli: advances and challenges. Front Microbiol 5:1-17. https://doi.org/10.3389/fmicb.2014.00172

Santos VP, Marques NSS, Maia PCSV, de Lima MAB, de Franco LO, de Campos-Takaki GM (2020) Seafood waste as attractive source of chitin and chitosan production and their applications. Int J Mol Sci 21:1-17. https://doi.org/10.3390/ijms21124290

Schmitz C, Auza LG, Koberidze D, Rasche S, Fischer R, Bortesi L (2019) Conversion of chitin to defined chitosan oligomers: current status and future prospects. Mar Drugs 17:452. https://doi.org/10. 3390/md17080452
Shivaji S, Chaturvedi P, Begum Z, Pindi PK, Manorama R, Padmanaban DA, Shouche YS, Pawar S, Vaishampayan P, Dutt CBS, Datta GN, Manchanda RK, Rao UR, Bhargava PM, Narlikar JV (2009) Janibacter hoylei sp. nov., Bacillus isronensis sp. nov. and Bacillus aryabhattai sp. nov., isolated from cryotubes used for collecting air from the upper atmosphere. Int J Syst Evol Microbiol 59:2977-2986. https://doi.org/10.1099/ijs.0.002527-0

Studier FW (2005) Protein production by auto-induction in high density shaking cultures. Protein Expr Purif 41:207-234. https://doi. org/10.1016/j.pep.2005.01.016

Tokuyasu K, Ohnishi-Kameyama M, Hayashi K (1996) Purification and characterization of extracellular chitin deacetylase from colletotrichum lindemuthianum. Biosci Biotechnol Biochem 60:15981603. https://doi.org/10.1271/bbb.60.1598

Wang Y, Song JZ, Yang Q, Liu ZH, Huang XM, Chen Y (2010) Cloning of a heat-stable chitin deacetylase gene from Aspergillus nidulans and its functional expression in Escherichia coli. Appl Biochem Biotechnol 162:843-854. https://doi.org/10.1007/ s12010-009-8772-Z

Wang X, Chi N, Bai F, Du Y, Zhao Y, Yin H (2016) Characterization of a cold-adapted and salt-tolerant exo-chitinase (ChiC) from $\mathrm{Pseu}$ doalteromonas sp. DL-6. Extremophiles 20:167-176. https://doi. org/10.1007/s00792-016-0810-5

Wattjes J, Sreekumar S, Richter C, Cord-Landwehr S, Singh R, El Gueddari NE, Moerschbacher BM (2020) Patterns matter part 1: chitosan polymers with non-random patterns of acetylation. React Funct Polym 151:104583. https://doi.org/10.1016/j.react functpolym.2020.104583

Win NN, Stevens WF (2001) Shrimp chitin as substrate for fungal chitin deacetylase. Appl Microbiol Biotechnol 57:334-341. https:// doi.org/10.1007/s002530100741

Yadav M, Goswami P, Paritosh K, Kumar M, Pareek N, Vivekanand V (2019) Seafood waste: a source for preparation of commercially employable chitin/chitosan materials. Bioresour Bioprocess 6:1-8. https://doi.org/10.1186/s40643-019-0243-y

Younes I, Rinaudo M (2015) Chitin and chitosan preparation from marine sources. Structure, properties and applications. Mar Drugs 13:1133-1174. https://doi.org/10.3390/md13031133

Zhao Y, Park RD, Muzzarelli RAA (2010) Chitin deacetylases: properties and applications. Mar Drugs 8:24-46. https://doi.org/10. 3390/md8010024

\section{Authors and Affiliations}

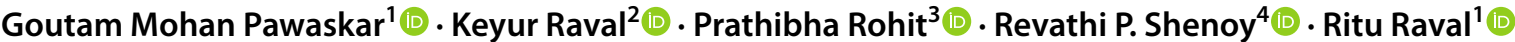

Goutam Mohan Pawaskar

goutam.pawaskar@learner.manipal.edu

Keyur Raval

keyurnraval@nitk.edu.in

Revathi P. Shenoy

revathi.shenoy@manipal.edu

1 Department of Biotechnology, Manipal Institute of Technology, Manipal Academy of Higher Education, Manipal 576104, India
2 Department of Chemical Engineering, National Institute of Technology Karnataka, Surathkal 575025, India

3 ICAR-Central Marine and Fisheries Research Institute, Mangalore 575001, India

4 Department of Biochemistry, Kasturba Medical College, Manipal Academy of Higher Education, Manipal 576104, India 